\title{
Development of Online Student Olympiad Training Materials for Elementary School Teachers in Magersari Mojokerto Subdistrict in the COVID-19 Pandemic Era
}

\author{
Manuharawati ${ }^{1}$, Raden Sulaiman², Hery Tri Sutanto ${ }^{3}$, Muhammad Jakfar ${ }^{4}$, Toni Phibeta ${ }^{5}$ \\ 1, 2, 3,4,5 Surabaya State University \\ Email: 1manuharawati@unesa.ac.id, 2radensulaiman@unesa.ac.id, 3herysutanto@unesa.ac.id, \\ 4muhammadjakfar@unesa.ac.id, 5toni.18075@mhs.unesa.ac.id

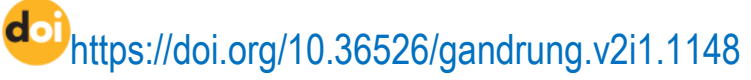

\begin{abstract}
In March 2020, the World Health Organization (WHO) declared COVID-19 as an international pandemic. This condition definitely affects the learning process, especially Mathematics learning in elementary school, and one of the goals expressed by Badan Standar Nasional Pendidikan (BSNP), namely that students have the ability to understand concepts, reason, solve problems, communicate ideas, and have an attitude of appreciating the usefulness of mathematics in life. Most elementary school teachers in Magersari District have not been able to do problem solving training for students and they need help to improve their abilities in assisting their students in solving Math Olympiad problems. Therefore, an activity was held to development of online student olympiad training materials for elementary school teachers in Magersari Mojokerto Subdistrict. Base on the evaluation, it can be concluded that this activity can improve the ability of teachers to develop Math Olympiad questions at the elementary school level and be able to solve them with problem solving steps; In solving problems related to integers, teachers can apply the properties of integer operations, and do not use formulas that are not familiar to elementary school children; And also, this activity is felt to be fun and in accordance with its objectives.
\end{abstract}

Keyword: COVID-19, Math Olympiad problems, problem solving

\section{Pendahuluan}

\section{A. Analisis Situasi}

Tiga bulan terakhir ini, seluruh wilayah di Indonesia digemparkan oleh datangnya pandemi yang dikenal dengan COVID-19 (Corona virus desease 19) yang mengakibatkan pada tanggal 11 Maret 2020, pihak Organisasi Kesehatan Dunia (WHO) menetapkan COVID-19 sebagai pandemi Internasional. Selanjutnya disusul oleh terbitnya Keputusan Presiden Republik Indonesia Nomor 11 tahun 2020 tentang Penetapan Kedaruratan Kesehatan Masyarakat COVID-19. Dalam Keppres tersebut, Presiden menetapkan COVID-19 sebagai jenis penyakit yang menimbulkan Kedaruratan Kesehatan Masyarakat serta menetapkan Kedaruratan Kesehatan Masyarakat Covid 19 di Indonesia yang wajib dilakukan upaya penanggulangannya sesuai dengan ketentuan peraturan perundang-undangan.

Sampai saat ini, penyebaran COVID-19 di Indonesia dari segi jumlah yang terpapar dan korban

Volume 2, Number 1, Februari 2021 | 62 Development of Online Student Olympiad Training Materials for Elementary School Teachers in Magersari Mojokerto Subdistrict in the COVID-19 Pandemic Era 
GANDRUNG: Jurnal Pengabdian Kepada Masyarakat ISSN: 2721-6136 (Online)

jiwa semakin bertambah. Sementara itu obat COVID-19 sampai saat ini di Indonesia belum tersedia. Ada ahli virus yang memprediksi bahwa obat COVID-19 akan siap di Indonesia pada sekitar bulan September 2020 (Kompas, 2020). Oleh karena itu untuk penekan penyebaran COVID-19 dianjurkan untuk: saling menjaga jarak, jaga kesehatan diri, meningkatkan imun tubuh, istirahat, dan olah raga yang cukup. Di Jawa Timur khususnya, hal ini diperkuat oleh dikeluarkannya aturan PSPB (Pembatasan Sosial Berskala Besar) Provinsi Jawa Timur. PSBB adalah pembatasan kegiatan tertentu penduduk dalam suatu wilayah yang diduga terinfeksi COVID-19 sedemikian rupa untuk mencegah kemungkinan penyebaran COVID19. Ditambah lagi tentang pernyataan Gubernur jawa Timur: "Seluruh wilayah di provinsi Jawa Timur sudah memasuki zona merah, yang berarti seluruh wilayah di Jawa Timur, ada kasus positf COVID-19" (Jawa Pos, 2020). Hal ini juga bersesuaian dengan keluarnya Surat Edaran Menteri Pendayagunaan Aparatur Negara dan Revormasi Birokrasi Indonesia Nomor 54 Tahun 2020.

Era Covid ini sangat mempengaruhi pembelajaran di Sekolah Dasar (SD), khususnya pembelajaran matematika. Salah satu tujuan diajarkan matematika diungkapkan oleh Badan Standar Nasional Pendidikan (BSNP), yaitu agar peserta didik memiliki kemampuan pemahaman konsep, penalaran, memecahkan masalah, mengkomunikasikan gagasan, dan memiliki sikap menghargai kegunaan matematika dalam kehidupan (BSNP, 2006). Dengan demikian, pembelajaran matematika dengan pemecahan masalah merupakan fokus penting. Disamping itu, pemecahan masalah sudah tampak pada proses pembelajaran pada Kurikulum 2013 dimana soal-soal yang ditampilkan mencakup masalah dengan berbagai penyelesaian (Sutrisno \& Razak, 2018). Selain melalui pembelajaran, untuk memberi semangat siswa SD dalam pemecahan masalah matematika, Dinas Pendidikan Provinsi Jawa Timur maupun Dinas Pendidikan di Kabupaten di Jawa Timur setiap tahun mengadakan olimpiade matematika.

Dari sisi lain, banyak guru mengalami kesulitan dalam mengajar siswa bagaimana memecahkan masalah matematika, yang akibatnya banyak siswa yang juga kesulitan dalam memecahkan masalah matematika, khususnya soal olimpiade matematika. Hal ini didasarkan Pengabdian Kepada Masyararakat yang dilakukan oleh Manuharawati, Yunianti, dan Jakfar (2018) dan (2019). Apalagi ditambah kondisi COVID-19 seperti saat ini.

Berdasarkan wawancara dengan Ketua Gugus 02 Kecamatan Magersari Mojokerto, sebagian besar guru SD di Kecamatan Magersari belum mampu melakukan pelatihan pemecahan masalah (soalsoal olimpiade) bagi siswa. Dengan kondisi akhir-akhir ini yang dihebohkan oleh adanya COVID-19 banyak guru SD di Kecamatan Magersari memerlukan bantuan untuk meningkatkan kemampuannya dalam mendampingi siswa-siswanya dalam memecahkan masalah olimpiade matematika. Dengan

Volume 2, Number 1, Februari 2021 | 63 Development of Online Student Olympiad Training Materials for Elementary School Teachers in Magersari Mojokerto Subdistrict in the COVID-19 Pandemic Era 
GANDRUNG: Jurnal Pengabdian Kepada Masyarakat ISSN: 2721-6136 (Online)

adanya aturan PSBB di Jawa Timur dan Surat Edaran Menteri Pendayagunaan Aparatur Negara dan Revormasi Birokrasi Indonesia Nomor 54 Tahun 2020, Tim Pengabdian Kepada Masyarakat (PKM) Jurusan Matematika Universitas Negeri Surabaya tidak mungkin mengadakan kegiatan pendampingan yang diminta oleh Guru-guru SD di Kecamatan Magersari Mojokerto tersebut secara langsung (tatap muka). Satu-satunya kemungkinan yang bisa dilakukan adalah mengadakan kegiatan pendampingan secara daring.

Salah satu materi matematika pada Kurikulum 2013 yaitu bilangan. Kompetensi dasar yang dicapai oleh siswa SD untuk materi bilangan diantaranya adalah dapat melakukan penjumlahan, pengurangan, perkalian, dan pembagian, perpangkatan, pengambilan akar bilangan yang melibatkan bilangan bulat, bilangan desimal, pecahan; menyelesaikan masalah yang berkaitan dengan faktor persekutuan terbesar (FPB) dan kelipatan persekutuan terkecil (KPK).

Berdasarkan uraian tersebut, Tim PKM berkeinginan untuk mengadakan kegiatan "Pengembangan Bahan Pelatihan Olimpiade Siswa via Daring Bagi Guru SD Kecamatan Magersari Mojokerto di Tengah COVID-19".

Tim PKM terdiri dari 4 orang dengan 2 orang mempunyai keahlian di bidang analisis, 1 orang di bidang aljabar, dan 1 orang di bidang stastistika. Dengan demikian, kegiatan yang diadakan sesuai dengan keahlian dari tim PKM.

\section{B. Permasalahan Mitra}

Dari analisis situasi, permasalahan yang dimiliki oleh guru-guru SD di Kecamatan Magersari Mojokerto adalah:

1. Masih kurangnya guru SD Kecamatan Magersari yang mempunyai kermampuan sebagai pelatih olimpiade matematika siswa SD, khususnya topik bilangan.

2. Belum adanya bahan pelatihan olimpiade siswa SD di Kecamatan Magersari Mojokerto di era pandemi COVID-19.

\section{Solusi dan Target Luaran}

Berdasarkan permasalahan yang dialami mitra, maka tim pengusul memiliki solusi dengan mengadakan kegiatan pelatihan pemecahan masalah matematika (soal olimpiade) khususnya topik bilangan dengan mengacu pada langkah-langkah penyelesaian masalah menurut Polya (1971).

Rencana kegiatan pelatihan pemecahan masalah yang akan diadakan adalah :

1. Secara daring, narasumber memaparkan tentang pemecahan masalah beserta strategi yang terkait. 
GANDRUNG: Jurnal Pengabdian Kepada Masyarakat ISSN: 2721-6136 (Online)

2. Secara daring, narasumber memberikan contoh penyelesaian soal matematika yang terkait dengan strategi pemecahan masalah. Soal-soal matematika yang akan dibahas terkait dengan :

a. Operasi dasar bilangan bulat (penjumlahan, pengurangan, perkalian, pembagian).

b. Operasi perpangkatan dan akar kuadrat.

c. Deret.

d. Operasi hitung pada pecahan.

e. FPB dan KPK

3. Secara daring, Tim pendamping (nara sumber dan mahasiswa) mendampingi peserta kegiatan dalam menyelesaikan soal-soal yang berkaitan dengan materi yang telah diberikan dengan menggunakan strategi pemecahan masalah.

4. Secara daring, peserta mendiskusikan hasil penyelesaian soal-soal matematika tersebut.

Selain itu untuk melihat ada tidaknya peningkatan kemampuan peserta dalam menerima materi, tim pengusul memberikan pre test dan post test dalam kegiatan tersebut. Luaran untuk kegiatan PKM ini adalah peningkatan pemahaman dan kemampuan peserta dalam menyelesaikan permasalahan matematika (khususnya topik bilangan) dengan pemecahan masalah.

\section{Metode}

Metode pelaksanaan dalam kegiatan PKM ini adalah metode ceramah, diskusi, dan penugasan yang kami rujuk dari Manuharawati, Yunianti, dan Jakfar (2018 dan 2019) namun dilakukan secara daring dengan alur kegiatan sebagai berikut:

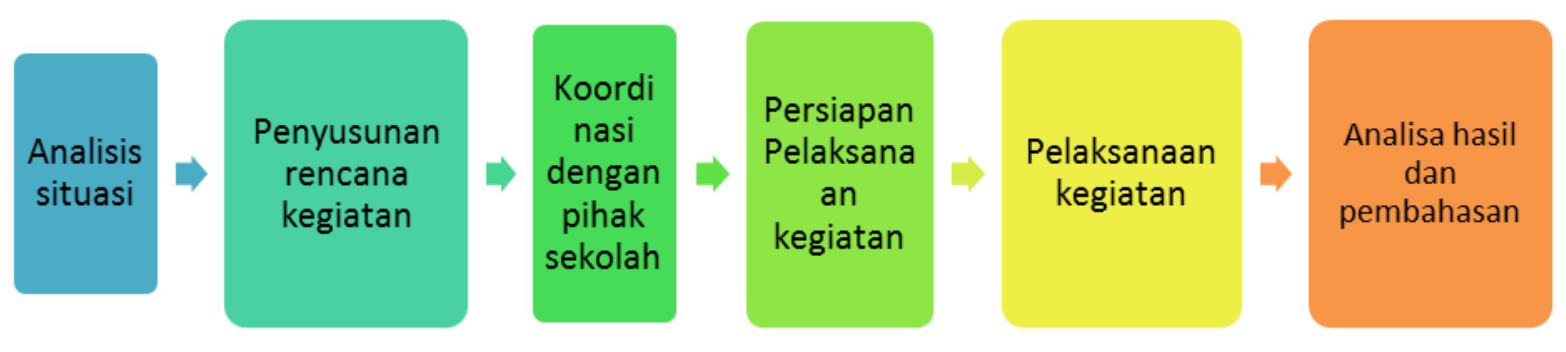

Diagram 1. Diagram alur pelaksanaan kegiatan

Penjelasan Diagram 1 sebagai berikut:

a. Analisis situasi

Analisis situasi dilakukan untuk mengetahui permasalahan yang dialami mitra. Metode yang 
digunakan adalah wawancara dengan pihak terkait dan pengamatan. Dari analisis situasi diperoleh permasalahan bahwa sebagian besar guru-guru belum menggunakan tahap-tahap pemecahan masalah dalam pembelajaran matematika SD (khususnya topik bilangan).

b. Penyusunan rencana kegiatan

Setelah permasalahan mitra diketahui, langkah selanjutnya menyusun rencana kegiatan. Rencana kegiatan adalah mengadakan kegiatan dalam bentuk pelatihan dengan tim pelaksana sebagai narasumber dan pendamping kegiatan. Dalam kegiatan ini juga dibantu oleh mahasiswa prodi pendidikan matematika FMIPA Unesa. Selain itu tim pendamping membuat rancangan bahan pelatihan yng akan dilakukan secara daring (pembuatan video materi pendampingan dan soal-soal Untuk pre tes, post e, maupun untuk penugasan secara daring).

c. Koordinasi dengan pihak sekolah

Setelah rencana disusun, kemudian pengusul melakukan koordinasi dengan pihak sekolah untuk menentukan waktu, serta persiapan sarana dan prasarana sehingga kegiatan dapat terlaksana.

d. Persiapan pelaksanaan kegiatan

Sebelum kegiatan dilaksanakan, persiapan kegiatan yang dilakukan adalah :

1. Koordinasi untuk pembagian tugas tim pelaksana

2. Mempersiapkan materi yaitu konsep pemecahan masalah dan contoh penggunaannya dalam materi bilangan SD, serta Pengembangan soal dan penyelesaiannya

3. Mempersiapkan soal pre test dan post test

4. Mempersiapkan angket peserta

e. Pelaksanaan kegiatan

Pelaksanaan kegiatan dilaksanakan sesuai kesepakatan tim dengan mitra yang terkait baik waktu maupun tempatnya. Untuk guru-guru Yang masuk di sekolah tempat di sekolah masing-masing Selain itu, ketika sesi penyelesaian permasalahan matematika, narasumber akan mengkondisikan peserta agar melalui 4 tahapan dalam pemecahan masalah yaitu memahami masalah, merencanakan pemecahannya, menyelesaikan masalah sesuai rencana, dan memeriksa kembali hasil yang diperoleh (looking back). Untuk kegiatan pengembangan soal, nara sumber memberi contoh soal dan bagaimana cara mengembangkan soal yang mirip tetapi mempunyai peneyelesaian yang sama ataupun berbeda

f. Analisa hasil dan pembahasan

Hasil pre test, post test akan dianalisa untuk mengetahui peningkatan kemampuan peserta dalam menerima materi. Sedangkan hasil angket akan digunakan untuk mengetahui respon peserta 
GANDRUNG: Jurnal Pengabdian Kepada Masyarakat ISSN: 2721-6136 (Online)

terhadap kegiatan. Setelah itu, hasil analisa tersebut akan ditelaah (dibahas) lebih lanjut sehingga bisa dihasilkan kesimpulan dari kegiatan PKM. Kemudian tim akan menyusun laporan akhir dan artikel untuk dipublikasikan.

\section{Hasil dan Diskusi}

\section{A. Persiapan}

Pada proses persiapan sebelum Kegiatan PKM tentang "Pengembangan Bahan Pelatihan Olimpiade Siswa Via daring Bagi Guru SD Kecamatan Magersari Mojokerto di Tengah Covid-19" dilaksanakan, tim pelaksana PKM (calon nara sumber) mempersiapkan hal-hal yang terkait dengan kegiatan tersebut, yaitu

1. Mengembangkan bahan pelatihan tentang langkah-langkah pemecahan masalah matematika (soal olimpiade) Matematika SD, serta contoh-contoh pengembangan soal olimpiade matematika SD.

2. Mengembangkan soal pretest dan posttest untuk peserta (guru-guru SD), yang akan digunakan untuk mengetahui peningkatan kemampuan guru dalam mengembangkan soal olimpiade matematika.

3. Mengembangkan instrument kepuasan peserta terkait kegunaan materi yang diberikan terhadap bidang peserta; kesesuaian kepakaran nara sumber dengan bidang yang disampaikan, dan untuk mengetahui leberlanjutan setelah kegiatan pendampingan selesai.

Menyusun rencanna pelaksanaan. Kegiatan ini menghasilkan jadwal pelaksanaan kegiatan pendampingan sebagai berikut (Tabel 1)

Tabel 1. Jadwal Kegiatan

\begin{tabular}{cllc}
\hline No & \multicolumn{1}{c}{ Hari/Tanggal } & \multicolumn{1}{c}{ Kegiatan } & $\begin{array}{c}\text { Penanggung- } \\
\text { jawab }\end{array}$ \\
\hline 1 & Sabtu & $\begin{array}{l}\text { Pretest. } \\
\text { 26 September 2020 }\end{array}$ & Penyampaian materi pemecahan masalah \\
\hline 2 & $\begin{array}{l}\text { Minggu } \\
27 \text { September 2020 }\end{array}$ & $\begin{array}{l}\text { Penyampaian materi pengembangan soal olimpiade } \\
\text { matematika dan penyelesaiannya. } \\
\text { Posttest. }\end{array}$ & Tim \\
\hline 3 & $\begin{array}{l}\text { Sabtu } \\
\text { 3 Oktober 2020 }\end{array}$ & $\begin{array}{l}\text { Workshop pengembangan soal olimpiade matematika } \\
\text { SD }\end{array}$ & Tim \\
\hline 4 & $\begin{array}{l}\text { Sabtu } \\
\text { 10 Oktober 2020 }\end{array}$ & $\begin{array}{l}\text { Workshop penyusunan penyelesaian soal olimpiade } \\
\text { yang sudah dikembangkan }\end{array}$ & Tim \\
\hline 5 & $\begin{array}{l}\text { Minggu } \\
\text { 11 Oktober 2020 }\end{array}$ & $\begin{array}{l}\text { Diskusi dan presentasi tentang pengembangan soal } \\
\text { olimpiade matematika SD dan penyelesaiannya }\end{array}$ & Tim \\
\hline
\end{tabular}


GANDRUNG: Jurnal Pengabdian Kepada Masyarakat ISSN: 2721-6136 (Online)

\section{B. Pelaksanaan}

Pelaksanaan Kegiatan PKM tentang "Pengembangan Bahan Pelatihan Olimpiade Siswa Via daring Bagi Guru SD Kecamatan Magersari Mojokerto di Tengah Covid-19"ini telah dilaksanakan pada tanggal 26 - 27 September 2020, 3, 10, dan 11 Oktober 2020 secara daring dengan jadwal seperti pada Tabel 2. Untuk memudahkan koordinasi, pada pelaksanaan tersebut, tim pelaksana (nara sumber) berada pada tempat yang sama, yaitu di Jurusan Matematika, FMIPA Unesa, Gedung C8.

Pada tanggal 26 dan 27 September 2020, kegiatan diikuti oleh 40 peserta, namun demikian hanya ada 35 peserta yang mengumpulkan hasil pretest. Dari 35 peserta:

1. Untuk soal Nomor 1 dan 2 tentang pemecahan masalah, hanya $11,43 \%$ (4 orang) saja yang cara penyelesaiannya menggunakan langkah-langkah pemecahan masalah. Hampir 97\% dari mereka menyelesaikan soal Nomor 1 dan Nomor 2 menggunakan rumus barisan dan deret yang mana materi ini tidak /belum diajarkan di tingkat SD 2, 86\% yang menggunakan sifat operasi jumlahan bilangan bulat).

2. Untuk Soal Nomor 3 , tentang pengembangan soal matematika SD, hanya $28,57 \%$ yang membuat soal dengan informasi lengkap serta konsep yang digunakan tidak salah. Contoh hasil penyelesaian Soal nomor 3, tentang pengembangan soal matematika SD dan contoh penyelesaian Soal Nomor 1 dan 2 adalah sebagai berikut (Gambar 1).

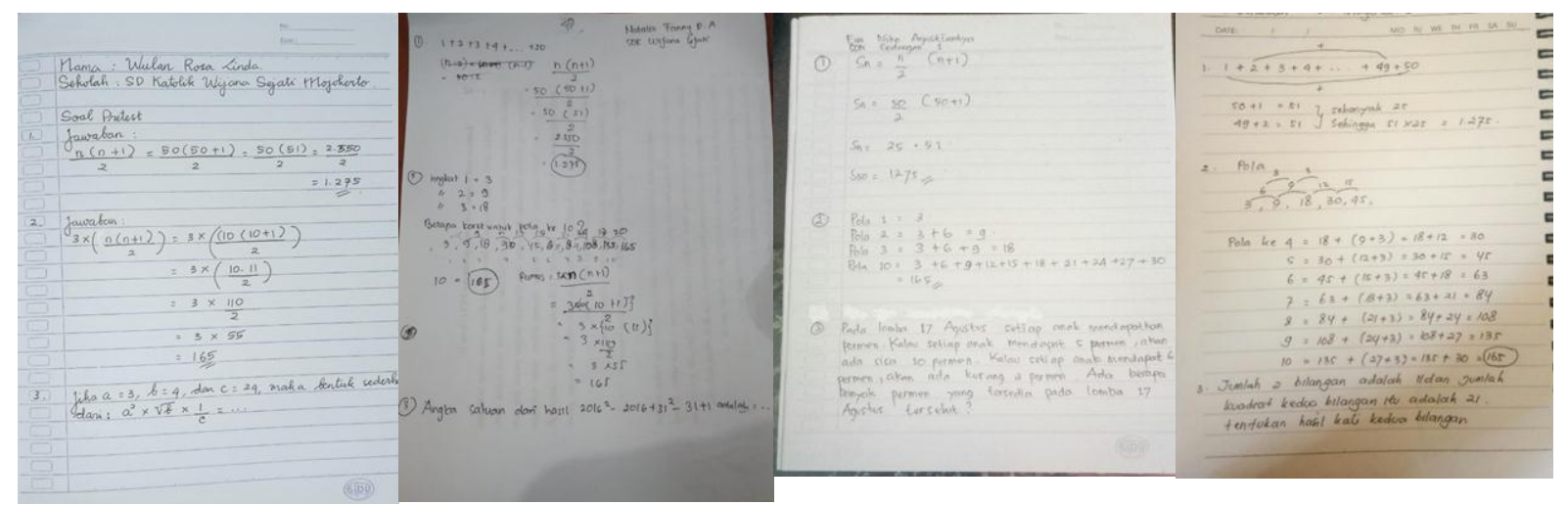

Gambar 1. Contoh hasil penyelesaian soal no. 1, 2, dan 3

Pada kegiatan posttest, 35 yang mengumpulkan jawaban dan 82,86\% dari mereka sudah menggunakan langkah-langkah penyelesaian masalah; dan 100\% cara menyelesaikannya dengan menggunakan sifat-sifat operasi jumlahan bilangan bulat.

Contoh penyelesaian soal posttest adalah sebagai berikut:

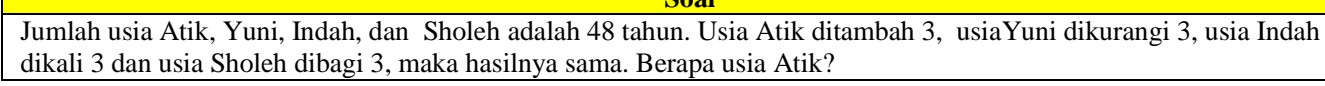

Volume 2, Number 1, Februari 2021 | 68 Development of Online Student Olympiad Training Materials for Elementary School Teachers in Magersari Mojokerto Subdistrict in the COVID-19 Pandemic Era 


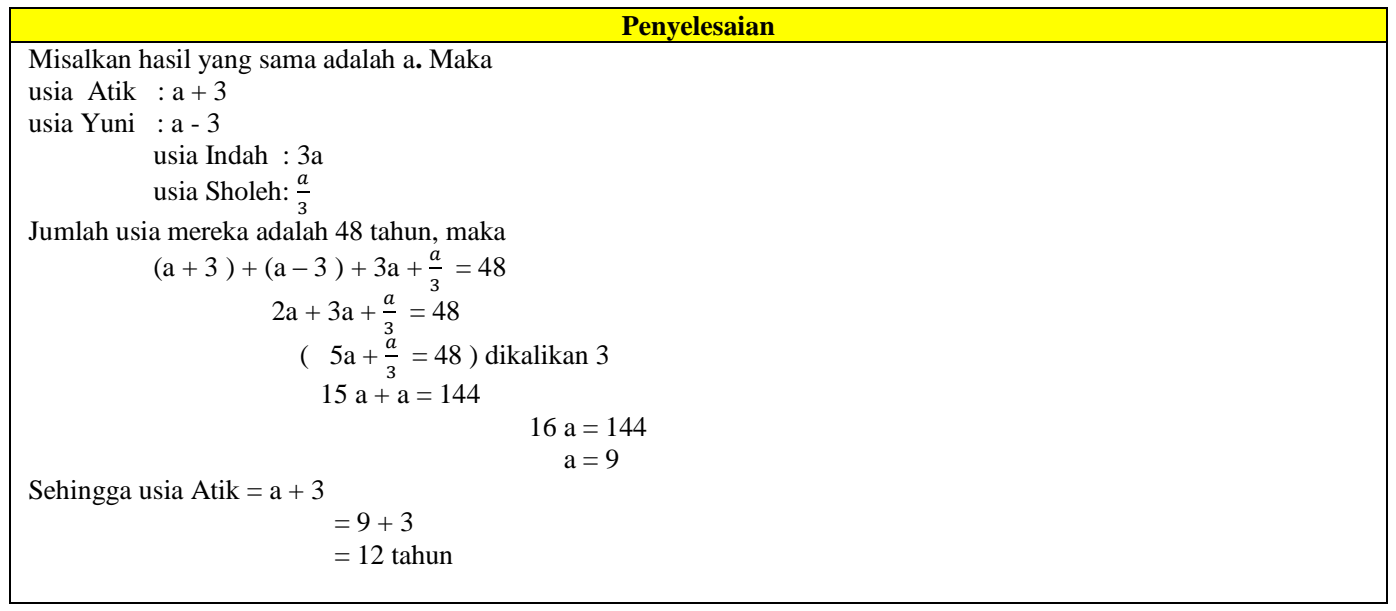

Pada kegiatan pengembangan soal olimpiade matematika SD, sebanyak 35 yang menggumpulkan dan hanya ada 4 orang yang masih salah konsep. Sisanya 88,57\% hanya redaksi yang perlu ada penyempurnaan. Kesalahan konsep yang dilakukan misalnya pada persamaan, sementara soalnya tidak memuat persamaan, meminta mencari volume kerucut dengan diketahui jari-jari kerucut, sementara kerucut tidak mempunyai jari-jari, Jadi dalam hal ini dia slah konsep tentang apa itu kerucut dana pa itu jari-jari.

Contoh pengembangan soal yang dikumpulkan adalah sebagai berikut

1. Contoh yang tidak lengkap dan salah konsep

\begin{tabular}{|l|l|}
\hline \multicolumn{1}{|c|}{ Soal } & \multicolumn{1}{|c|}{ Penyelesaian } \\
\hline Pada persamaan $\mathrm{x}^{2}-3 \mathrm{x}+1$. Tentukan nilai dari $\mathrm{X}_{1}+$ & $\mathrm{a}=1, \mathrm{~b}=-3, \mathrm{c}=1$ \\
$\mathrm{X}_{2}$ Jika $\mathrm{X}_{1}$ dan $\mathrm{X}_{2}$ adalah akar - akar penyelesaian & $\mathrm{X}_{1}+\mathrm{X}_{2}=-\frac{b}{a} \rightarrow \mathrm{X}_{1}+\mathrm{X}_{2}=\frac{3}{1}=3$ \\
persamaan tersebut. & $\mathrm{X}_{1} \cdot \mathrm{X}_{2}=\frac{c}{a} \rightarrow \mathrm{X}_{1} \cdot \mathrm{X}_{2}=\frac{1}{1}=1$ \\
& $\mathrm{X}_{1}{ }^{2}+\mathrm{X}_{2}{ }^{2}=\left(\mathrm{X}_{1}+\mathrm{X}_{2}\right)^{2}-2 \mathrm{X}_{1} \cdot \mathrm{X}_{2}=3^{2}-2(1)=7$ \\
\hline
\end{tabular}

2. Contoh yang sudah bagus

\section{Soal}

Suatu keluarga memiliki beberapa anak. Salah satu anak laki-lakinya adalah Afan dan salah satu anak perempuannya adalah Yeni. Banyaknya saudara laki-laki Afan adalah dua kali banyaknya saudara perempuannya. Banyaknya saudara laki-laki Yeni adalah lima kali banyaknya saudara perempuannya. Banyak anak pada keluarga itu adalah ....

Penyelesaian

Dan banyak anak perempuan adalah $n$

Maka, banyaknya saudara laki-laki Afan adalah dua kali banyaknya saudara perempuannya, dapat dituliskan :

$\mathrm{m}-1=2 n$ (Afan tidak dihitung) (1)

- Karena Afan tidak dihitung, maka yang digunakan adalah m-1, bukan $\mathrm{m}$

- Banyak saudara laki-laki Yeni adalah lima kali banyaknya saudara perempuannya, dapat dituliskan: $\mathrm{m}=5$ (n-1) (Yeni tidak dihitung)

- Karena Yeni tidak dihitung, maka yang digunakan adalah $\mathrm{f}-1$, bukan $\mathrm{f}$

- Sehingga persamaan (2) dapat masuk ke persamaan (1)

- $\mathrm{m}-1=2 n .5(\mathrm{n}-1)-1=2 \mathrm{n}$

$5 \mathrm{n}-5-1=2 \mathrm{n}$

$5 \mathrm{n}-6=2 \mathrm{n}$

$5 \mathrm{n}-2 \mathrm{n}=6$

$3 n=6$

Volume 2, Number 1, Februari 2021 | 69 


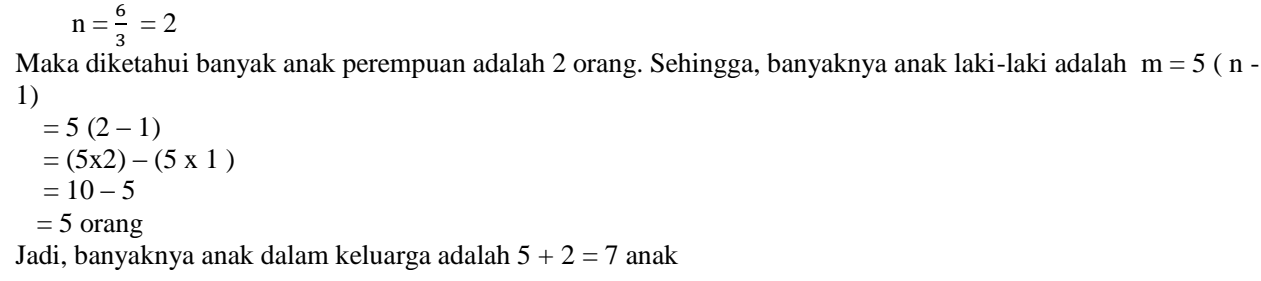

\section{Evaluasi}

Evaluasi kepuasan peserta terhadap pelaksanaan kegiatan diperoleh dari isian, komentar dan saran yang diperoleh dari angket respon peserta. Dari 40 peserta hanya 31 peserta yang mengisi angket. Dari 31 tersebut, Peserta yang mengisi angket (respon) kepusan sebanyak 31 dari 40 peserta. Instrumen angket kepuasan berisi pertanyaa-pertanyaan terkait kepuasan peserta terhadap kegiatan PKM ini yang ditinjau dari segi minat dan motifasi peserta, segi materi, segi pemateri, dan segi efektifitas kegiatan.

1. Dari segi minat dan motivasi: sebanyak $74.2 \%$ peserta mengikuti kegiatan ini berdasarkan bidang keahlian, sebanyak $96.8 \%$ peserta antusias, dan sebanyak $96.8 \%$ termotivasi untuk menerapkan materi kegiatan ini.

2. Dari segi materi: sebanyak $93.5 \%$ peserta meyakini materi kegiatan ini dapat meningkatkan kemampuan peserta dalam memecahkan masalah (teutama soal terkait Olimpiade), sebanyak 90.3\% peserta menjawab materi kegiatan ini sesuai kebutuhan peserta, dan sebanyak $93.5 \%$ peserta merasa materi kegiatan ini mudah dipahami.

3. Dari segi pemateri: sebanyak $96.8 \%$ peserta menilai pemateri menguasai materi, sebanyak 96\% peserta menilai Pemateri menyampaikan materi dengan jelas dan mudah, sebanyak 90.3\% peserta menilai pemateri menyampaikan materi dengan variatif, sebanyak $96.8 \%$ peserta menilai pemateri responsif terhadap pertanyaan peserta, sebanyak $96.8 \%$ peserta menilai Pemateri menjalin komunikasi yang baik terhadap peserta, dan sebanyak $96.8 \%$ peserta menilai Pemateri terbuka dalam menerima masukan/kritik.

4. Segi Efektifitas: sebanyak $93.5 \%$ peserta merasa waktu yang disediakan untuk acara ini memadai, sebanyak $93.5 \%$ peserta merasa tujuan peserta mengikuti kegiatan ini tercapai, $96.8 \%$ merasa kegiatan ini berjalan menyenangkan, dan $83.9 \%$ merasa kegiatan ini berjalan efektif.

5. Beberapa saran dengan komentar-komentar yang positif dan berharap kelanjutan kegiatan ini dapat dilihat pada Tabel 2. 
Tabel 2. Saran dari peserta

\begin{tabular}{cl}
\hline No. & \multicolumn{1}{c}{ Kritik dan Saran } \\
\hline 1 & $\begin{array}{l}\text { Jika di lain hari terdapat kesempatan untuk melakukan webinar, alangkah lebih baiknya } \\
\text { dilaksanakan di hari efektif }\end{array}$ \\
\hline 2 & Mohon ada kelanjutan pelatihan tatap muka saat pandemi berakhir \\
\hline 3 & Sangat memuaskan \\
\hline 4 & Jos \\
\hline 5 & $\begin{array}{l}\text { Semoga kegiatan ini bisa berlanjut lagi agar kami bisa mengembangkan potensi kami dalam } \\
\text { pembelajaran untuk olimpiade }\end{array}$ \\
\hline 6 & Materi lebih bervariasi, diadakan secara berkala, diadakan saat jam kerja \\
\hline 7 & KKG sebaiknya bekerja sama dengan Unesa untuk RTL dalam kegiatan ini \\
\hline 8 & $\begin{array}{l}\text { Bagus sekali, mudah2an bisa berlanjut dan materi bermanfaat sekali . Trimakasih bpk / ibu } \\
\text { dosen UNESA . }\end{array}$ \\
\hline 9 & $\begin{array}{l}\text { Alhamdulillah, materi yang disampaikan sangat bermanfaat. Hanya saja karena terkendala } \\
\text { sinyal sehingga suara kurang jelas. Terima kasih untuk bapak ibu pemateri, semoga } \\
\text { senantiasa diberikan kesehatan dan kesuksesan. Amiii }\end{array}$ \\
\hline
\end{tabular}

Berikut adalah contoh foto kegiatan peserta sedang antusias memperhatikan pendampingan langkah-langkah pemecahan masalah/soal olimpiade matematika SD dan pengembangan soal (Gambar 2).

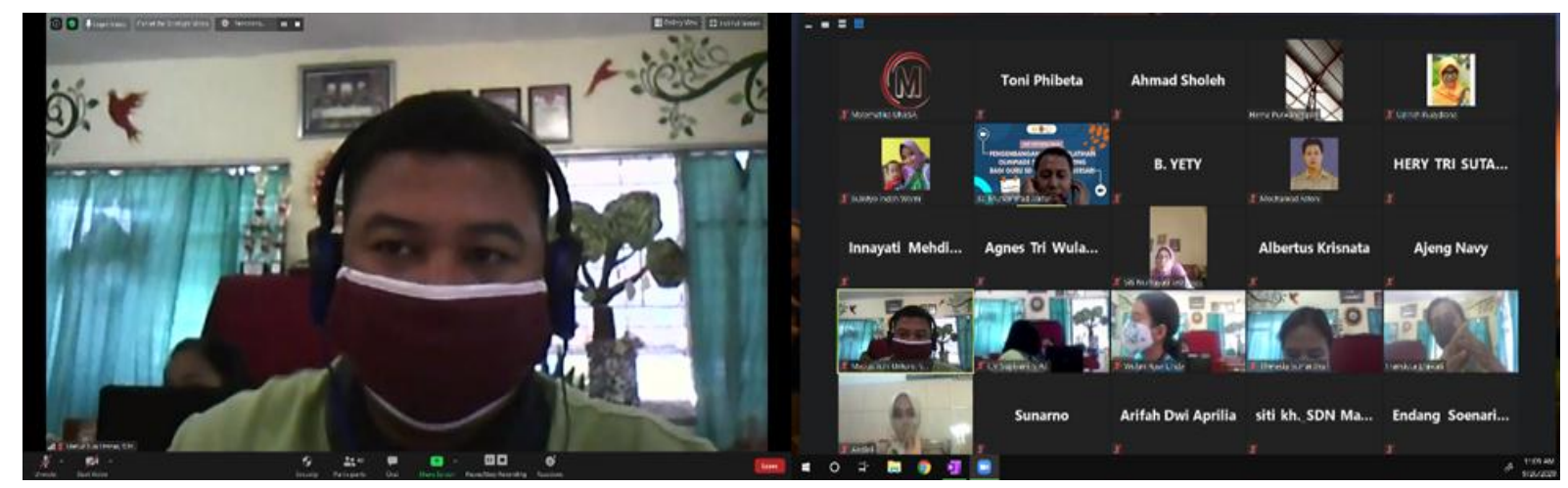

Gambar 2. Foto peserta saat kegiatan berlangsung

\section{Kesimpulan}

Berdasarkan hasil pretest, posttest, dan isian angket dapat disimpulkan bahwa; (1) Kegiatan PKM ini berhasil, dapat meningkatkan kemampuan guru (dari 28,57\% menjadi $82,57 \%$ dari total peserta) dalam mengembangkan soal olimpiade matematika SD dan mampu menyelesaikannya dengan langkahlangkah penyelesaian masalah, (2) Dalam menyelesaikan masalah yang terkait dengan bilangan bulat bisa menerapkan sifat-sifat operasi bilangan bulat, dan tidak menggunakan rumus-rumus yang belum dikenal oleh anak SD, dan (3) Kegiatan dirasa menyenangkan dan sesuai dengan tujuannya, dan peserta akan merasa lebih senang jika kegiatan ini dilanjutkan dengan adanya kerjasama antara dinas 
GANDRUNG: Jurnal Pengabdian Kepada Masyarakat ISSN: 2721-6136 (Online)

pendidikan Mojokerto dengan Unesa.

\section{Daftar Referensi}

BSNP. (2006). Standar Isi untuk Satuan Pendidikan Dasar dan Menengah. Jakarta : BSNP.

CNBC-Indonesia. (2020). Mohon Doanya, Obat Vaksin Covid 19 Siap September Ini. CNBC-Indonesia. diakses 13 April 2020

Jawa Pos. 2020. Semua Wilayah Zona Merah, Gubernur Kaji Penerapan PSBB Seluruh Jawa Timur, diakses 15 Mei 2020

Manuharawati, Yunianti, D. N., \& Jakfar, M. (2018). Peningkatan Kompetensi Materi Aljabar Bagi guru SD di Kediri Melalui Pembinnaan Olimpiade Matematika. Prosiding Semnas PPM 2018. Surabaya: LPPM Unesa.

Manuharawati, Yunianti, D. N., Sutanto, H. T., \& Jakfar, M. (2019). Pelatihan Pemecahan Masalah Matematika Materi Bilangan Bagi Guru-guru Sekolah Dasar di Ponorogo Jawa Timur Unesa. Laporan PKM 2019. Surabaya: LPPM.

Menteri Pendayagunaan Aparatur Negara dan Revormasi Birokrasi. 2020. Surat Edaran Menteri Pendayagunaan Aparatur Negara dan Revormasi Birokrasi Nomor 54 Tahun 2020, tentang Perubahan Ketiga Atas Surat Edaran Menteri Pendayagunaan Aparatur Negara dan Revormasi Birokrasi.Nomor 19 Tahun 2020 Tentang Penyesuaian Sistem Kerja Aparatur Sipil Negara Dalam Upaya Pencegahan Penyebaran Covid 19 di lingkungan Instansi Pemerintah

Polya, G. (1971). How to Solve It: A New Aspect of Mathematics Method. New Jersey: Princeton University Pres.

Presiden Republik Indonesia. 2020. Keputusan Presiden Rebublik Indonesia Nomor 11 Tahun 2020, tentang Penetapan Kedaruratan Kesehatan Masyarakat Corona Virus Disease 2019 (Covid-19).

Presiden Republik Indonesia. 2020. Peraturan Pemerintah Republik Indonesia Nomor 21 Tahun 2020, tentang Pembatasan Sosial berskala Besar Dalam Rangka Percepatan Penanganan Corona Virus Disease 2019 (Covid-19).

Sutrisno, A. B., \& Razak, F. (2018). Eskripsi Pemecahan Masalah Matematika Berdasarkan Langkah Polya Ditinjau dari Kepribadian Siswa Phlegmatis. Jurnal Pendidikan Matematika, 2(2), 120-131. 